\title{
NITROGEN FRACTIONS IN SPENT MUSHROOM SUBSTRATE
}

\author{
Marcin Becher, Krzysztof Pakuła \\ Chair of Soil Science and Plant Nutrition \\ Siedlce University of Natural Science and Humanities
}

\begin{abstract}
In the last decade, Poland has become the leader in mushroom production in Europe. Mushroom cultivation generates large amounts of spent substrate, which is a waste material and must be recycled. The substantial content of macroelements, including nitrogen, prompts using this organic material as a soil fertilizer.

The objective of the paper was to determine the proportion of nitrogen in different forms extracted from spent mushroom substrates. The studies were aimed at determining the potential for the rational use of spent mushroom substrate in soil fertilization. The sequential extraction of nitrogen compounds was performed with a $0.25 \mathrm{M} \mathrm{KCl}$ solution (for the extraction of mineral nitrogen forms and the most labile organic nitrogen compounds) and with $0.25 \mathrm{M}$ and $0.25 \mathrm{M} \mathrm{H}_{2} \mathrm{SO}_{4}$ (hot hydrolysis for sequencing of organic nitrogen linkage that are easily hydrolysing and difficult to hydrolyse). The prepared solutions were tested for the total content of nitrogen with the method by Kjeldahl and for carbon with the oxidative-potentiometric method. The samples were also subjected to extraction of nitrogen bound to humic substances. It was found that spent mushroom substrate had a substantial potential for enriching fertilized soil with organic nitrogen compounds, which are, to a large extent, potentially liable to degradation. In summary, approximately $2 / 3$ of the total nitrogen pool in the organic complexes and about $1 / 3$ of the carbon pool were extracted using sequential extraction with a neutral salt solution and acid hydrolysis at different concentrations of hydrogen ions. The calculated $\mathrm{C} / \mathrm{N}$ values suggest that the extracted organic compounds are vulnerable to degradation and indicate the resistance of compounds present in post-extraction residues. While fractioning organic matter, it was found that a relatively large amount of nitrogen was sequenced at the stage of decalcification of the samples, and the proportion of humic substances equalled about $1 / 5$ of the total content of this element.
\end{abstract}

Key words: spent mushroom substrate, nitrogen fractions, acid hydrolysis.

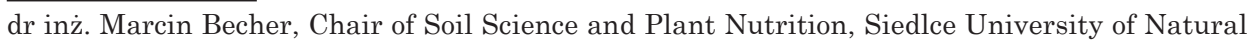
Science and Humanities, Prusa 14, 08-110 Siedlce, Poland, e-mail: mbecher@uph.edu.pl 


\title{
FRAKCJE AZOTU W PODŁOŻU POPIECZARKOWYM
}

\begin{abstract}
Abstrakt
W ostatniej dekadzie Polska stała się liderem produkcji pieczarek w Europie. Podczas uprawy powstaje duża ilość zużytego podłoża, które jako odpad musi podlegać utylizacji. Znaczna zawartość makroelementów, w tym azotu, zachęca do wykorzystania tego organicznego materiału odpadowego do nawożenia gleb.

Celem pracy była ocena udziału różnych form azotu wydzielonych z podłoża po uprawie pieczarki. Badania prowadzono uwzględniając perspektywę racjonalnego wykorzystania zużytego podłoża do nawożenia gleb. Do sekwencyjnego wydzielenia związków azotu zastosowano roztwory $0,25 \mathrm{M} \mathrm{KCl}$ (do wyekstrahowania mineralnych oraz najbardziej labilnych organicznych form azotu) oraz 0,25 $\mathrm{M}$ i 2,5 $\mathrm{M} \mathrm{H}_{2} \mathrm{SO}_{4}$ (hydroliza na gorąco - do wydzielenia organicznych połączeń azotu, łatwo i trudno ulegających hydrolizie). W uzyskanych roztworach oznaczono ogólna zawartość azotu metodą Kjeldahla, a węgla - metodą oksydacyjno-miareczkową. W pobranych próbkach wykonano także ekstrakcję azotu związanego z substancjami humusowymi. Stwierdzono duży potencjał podłoża popieczarkowego do wzbogacania nawożonych gleb w zwiąki organiczne azotu, w znacznym stopniu potencjalnie podatnych na procesy rozkładu. W sumie, za pomoca ekstrakcji sekwencyjnej z wykorzystaniem roztworu soli obojętnej oraz w wyniku hydrolizy kwaśnej o różnym stężeniu jonów wodorowych wydzielono ok. $2 / 3$ całkowitych zasobów azotu w połączeniach organicznych oraz ok. 1/3 zasobów węgla. Obliczone wartości C/N sugerują podatność na procesy rozkładu wydzielonych związków organicznych oraz odporność związków w poekstrakcyjnej pozostałości. Podczas frakcjonowania materii organicznej stwierdzono relatywnie dużą ilość azotu wydzielonego na etapie dekalcytacji próbek, a udział azotu substancji humusowych wynosił ok. 1/5 całkowitej zawartości tego pierwiastka.
\end{abstract}

Słowa kluczowe: podłoże popieczarkowe, frakcje azotu, hydroliza kwaśna.

\section{INTRODUCTION}

In the last decade, following the introduction of modern cultivation systems and the concentration of large-scale industrial mushroom producing operations located mainly in the eastern part of the province of Mazowieckie, Poland has become the leader in mushroom production in Europe. According to the Polish regulations, spent mushroom substrate, as a by-product of mushroom cultivation, is regarded to be waste material (Regulation ... 2001). This has prompted a search for methods for its rational and judicious utilization. This organic waste material, which in modern cultivation techniques is disinfected (at $70^{\circ} \mathrm{C}$ ) following mushroom collection, contains:

- substrate for mushroom cultivation (the most important quantitative component) made of straw and chicken manure (often with the addition of peat, urea, soy protein, dolomite or gypsum);

- surface cover made of valley peat with an alkalizing compound (which contains $\mathrm{CaCO}_{3}$ );

- remnant mycelium and unharvested mushroom fruiting bodies.

Numerous studies on the elementary composition of spent mushroom substrate have demonstrated a substantial amount of organic matter and 
nutrients, including nitrogen (STEWART et al. 1998, ZMORA-NAHum et al. 2007, Jordan et al. 2008, Kalembasa, Majchrowska-Safaryan 2009, Medina et al. 2009, Rutkowska et al. 2009, Kalembasa, Becher 2011, 2012). The application of spent mushroom substrate as a soil fertilizer seems to be the most appropriate method for its utilization, as it improves the nitrogen balance in soil. It is particularly recommended for fertilization of soil with a low content of humus, where nitrogen is present at lower concentrations than required by plants, which reduces the profitability of plant production. The cultivated soil in the Siedlce Upland (Poland), where mushroom operations are concentrated, often has low humus and nitrogen reserves and good aerobic conditions, which makes them suitable for the recycling of spent mushroom substrate (Becher, Kalembasa 2011, PakuŁa, Kalembasa 2012, Becher 2013).

The speciation analysis of nitrogen compounds found in the organic matter of environmental samples consists in their hydrolysis with mineral acid or base solutions and in the quantitative analysis of hydrolysates (SCHULTEN, SCHNITZER 1998). Until recently, the studies conducted in the Department of Soil Sciences and Agricultural Chemistry, University of Natural Sciences and Humanities in Siedlce (Poland), have demonstrated that over 97\% of nitrogen reserves in spent mushroom substrate are enclosed in organic compounds with different resistance to degradation, of which $47 \%$ belong to the non-hydrolysing organic nitrogen pool (KALEMBASA, BECHER 2011).

The objective of the paper was to evaluate the proportion of nitrogen in the fractions sequenced from spent mushroom substrate. The study was encouraged by the need to rationalise applications of spent substrate in soil fertilization.

\section{MATERIAL AND METHODS}

The study was conducted in three modern mushroom producing operations located near Siedlce, Poland. The samples of spent substrate used for common mushroom, Agaricus bisporus, cultivation were collected from 8 cultivation rooms (with a shelf surface of $620 \mathrm{~m}^{2}$ ) following steam disinfection and immediately before the removal of substrate with mushrooms. In the selected rooms, the substrates for mushroom cultivation originated from different suppliers. The samples were collected from 23.10.2011 to 15.01.2012 with each being taken from five points. The averaged samples (DM, $n=8$ ) were dried at $40^{\circ} \mathrm{C}$, comminuted in an agate mill to particles $<25$ $\mathrm{mm}$ in diameter and chemically analysed (in three repetitions). The results were referred to the absolute dry matter of the tested material that was determined by weight after drying the substrate at $105^{\circ} \mathrm{C}$. The total content of carbon (TC) and nitrogen (TN) were determined on a Series II 2400 autoanalyser (Perkin Elmer) equipped with a thermal conductivity detector and 
acetanilide as the standard material. The sequential extraction of different nitrogen-containing compounds was performed by modifying the method described by Kalembasa (1995). The following solutions were used $(\mathrm{m} / \mathrm{v}=1 / 25)$ : $0.25 \mathrm{M} \mathrm{KCl}$ (extraction at room temperature for 3 hours); $0.25 \mathrm{M} \mathrm{H}_{2} \mathrm{SO}_{4}$ and $2.5 \mathrm{M} \mathrm{H}_{2} \mathrm{SO}_{4}$ (hydrolysis at boiling temperature of the mixture, under an aqueous reflux condenser for 3 hours); and concentrated $\mathrm{H}_{2} \mathrm{SO}_{4}$ (mineralization of organic compounds in residuum). Following the extraction and hydrolysis reactions, the solution was clarified by centrifugation (4000 rpm) and filtered through a $0.45 \mu \mathrm{m}$ filter. After each stage of the extraction procedure, the tested material was washed three times with deionised water. The applied method of sequential fractioning allowed us to define soil nitrogen in mineral and organic forms (operational fractions) with different potential degradibility in soil after fertilization (Table 1).

Table 1

Nitrogen forms and the methods of their recovery

\begin{tabular}{|c|c|}
\hline Nitrogen form (operational) & Method of recovery \\
\hline $\mathrm{N}-\mathrm{NH}_{4}$ - ammonia form & $\begin{array}{l}\text { distillation from } 0.25 \mathrm{M} \mathrm{KCl} \text { extract after } \\
\text { alkalization with } \mathrm{MgO}\end{array}$ \\
\hline $\mathrm{N}-\mathrm{NO}_{\mathrm{x}}$ - nitrate forms (III and V) & $\begin{array}{l}\text { distillation from } 0.25 \mathrm{M} \mathrm{KCl} \text { extract after } \\
\text { distillation with } \mathrm{N}^{-\mathrm{NH}_{4}} \text { and application } \\
\text { of Devard's reductive mixture }\end{array}$ \\
\hline $\mathrm{N}_{\mathrm{MIN}}-$ nitrogen in mineral compounds & $\mathrm{N}_{\mathrm{MIN}}=\mathrm{N}-\mathrm{NH}_{4}+\mathrm{N}-\mathrm{NO}_{\mathrm{x}}$ \\
\hline $\mathrm{N}_{\mathrm{ORG}}-$ nitrogen in organic compounds & $\mathrm{N}_{\mathrm{ORG}}=\mathrm{TN}-\mathrm{N}_{\mathrm{MIN}}$ \\
\hline $\mathrm{N}_{\mathrm{KCL}}$ & $\begin{array}{l}\text { measured in } 0.25 \mathrm{M} \mathrm{KCl} \text { extract after minera- } \\
\text { lization of the solution }\end{array}$ \\
\hline $\mathrm{N}_{\mathrm{OR}}-$ soluble organic nitrogen & $\mathrm{N}_{\mathrm{OR}}=\mathrm{N}_{\mathrm{KCl}}-\mathrm{N}_{\mathrm{MIN}}$ \\
\hline $\mathrm{N}_{\mathrm{OŁH}}$ - easily hydrolysing organic nitrogen & $\begin{array}{l}\text { measured after hydrolysis in } 0.25 \mathrm{M} \mathrm{H}_{2} \mathrm{SO}_{4} \\
\text { and mineralization of the solution }\end{array}$ \\
\hline $\begin{array}{l}\mathrm{N}_{\mathrm{OEH}}-\mathrm{NH}_{4}-\text { ammonia form in easily } \\
\text { hydrolysing fraction }\end{array}$ & $\begin{array}{l}\text { nitrogen distilled off from the hydrolysate } \\
\text { after alkalization with } 10 \mathrm{M} \mathrm{NaOH}\end{array}$ \\
\hline $\mathrm{N}_{\text {отн }}$ - organic nitrogen difficult to hydrolyse & $\begin{array}{l}\text { measured after hydrolysis in } 2.5 \mathrm{M} \mathrm{H}_{2} \mathrm{SO}_{4} \text { and } \\
\text { mineralization of the solution }\end{array}$ \\
\hline $\mathrm{N}_{\mathrm{ONH}}-$ non-hydrolysing organic nitrogen & $\begin{array}{l}\text { measured after post-extraction mineralization } \\
\text { of the residues in concentrated } \mathrm{H}_{2} \mathrm{SO}_{4}\end{array}$ \\
\hline
\end{tabular}

The total content of nitrogen was determined with the method by Kjeldahl. The mineralization of nitrogen incorporated in organic compounds present in the extraction solution was carried out in Kjeldahl's flasks, from which ammonium was distilled off immediately after mineralization.

The omission of dilution of the mineralized samples and the use of a micropipette for titration allowed for the determination of nitrogen in the samples with low concentrations of this element. The analytical fractioning procedure and determination of nitrogen in organic compounds were verified with acetanilide (the standard material, Perkin Elmer 0240-1121) (Table 2) 
Table 2

Verification of the procedure of quantitative nitrogen analysis

\begin{tabular}{|c|c|c|}
\hline $\begin{array}{c}\text { Expected value } \\
(\%)\end{array}$ & $\begin{array}{c}\text { Recorded value, mean for } n=5 \\
(\%)\end{array}$ & $\begin{array}{c}\text { Recovery } \\
(\%)\end{array}$ \\
\hline 10.36 & 10.24 & 98.8 \\
\hline
\end{tabular}

Table 3

Comparison of the summary nitrogen content in the sequenced fractions with the total content of this element

\begin{tabular}{|l|c|}
\hline Number of samples & 8 \\
\hline Number of sequential extractions & 24 \\
\hline Recovery (\%) $=\mathrm{N}_{\mathrm{KCL}}+\mathrm{N}_{\text {ОЕН }}+\mathrm{N}_{\text {ОТН }}+\mathrm{N}_{\text {ONH }} / \mathrm{TN} \cdot 100$ & \\
Range & $93.4-96.6$ \\
Mean & 94.5 \\
$\mathrm{SD}$ & 1.06 \\
\hline
\end{tabular}

SD - standard deviation

and by comparing the total amount of nitrogen in the selected fractions with the total content of this element in the sample (Table 3).

The solutions generated by fractioning were also tested for the content of carbon with the oxidative-potentiometric method (KALEMBASA 1991). The analogical fractions of organic carbon were identified: soluble $\left(\mathrm{C}_{\mathrm{OR}}\right)$, easily hydrolysing $\left(\mathrm{C}_{\mathrm{O} € \mathrm{H}}\right)$, difficult to hydrolyse $\left(\mathrm{C}_{\mathrm{OTH}}\right)$ and non-hydrolysing $\left(\mathrm{C}_{\mathrm{ONH}}\right)$. The calculations of $\mathrm{C}_{\mathrm{OR}}$ content included the amount of $\mathrm{Cl}^{-}$ions (derived from $\mathrm{KCl}$ ) that during mineralization of organic compounds cause the reduction of $\mathrm{Cr}^{6+}$ in $\mathrm{K}_{2} \mathrm{Cr}_{2} \mathrm{O}_{7}$. The amount of $\mathrm{C}_{\mathrm{ONH}}$ was calculated with the following formula: $\mathrm{C}_{\mathrm{ONH}}=\mathrm{TC}-\left(\mathrm{C}_{\mathrm{OR}}+\mathrm{C}_{\mathrm{OEH}}+\mathrm{C}_{\mathrm{OTH}}\right)$.

In addition, humic substances were extracted from the samples according to the following procedure: decalcification $\left(0.05 \mathrm{M} \mathrm{H}_{2} \mathrm{SO}_{4}\right) \rightarrow$ extraction of humic substances $(0.1 \mathrm{M} \mathrm{NaOH}) \rightarrow$ separation into humic acids and fulvic acids by means of acidification $-\mathrm{pH}=1.5$ (Dziadowiec, Gonet 1999). The extracted solutions were tested for the content of nitrogen with the method by Kjeldahl and the following fractions were obtained: $\mathrm{N}_{\text {DEKA }}$ - nitrogen in the fraction after decalcification; $\mathrm{N}_{\mathrm{SH}}$ - nitrogen in the fraction of humic substances (sequenced with $0.1 \mathrm{M} \mathrm{NaOH}$ ); $\mathrm{N}_{\mathrm{KH}}$ - nitrogen in the fraction of humic acids; $\mathrm{N}_{\mathrm{KF}}$ - nitrogen in the fraction of fulvic acids; $\mathrm{N}_{\mathrm{SNH}}$ - nitrogen in non-humified substances: $\mathrm{N}_{\mathrm{SNH}}=\mathrm{TN}-\left(\mathrm{N}_{\mathrm{DEKA}}+\mathrm{N}_{\mathrm{SH}}\right)$.

\section{RESULTS AND DISCUSSION}

The contents of nitrogen and carbon (Table 4) in the spent mushroom substrate indicate considerable potential for enrichment of soil with these 
Table 4

Selected parameters of the examined spent mushroom substrates

\begin{tabular}{|c|c|c|c|c|}
\hline & \multirow{2}{*}{$\begin{array}{c}\text { Dry } \\
\text { Sample }\end{array}$} & \multicolumn{2}{|c|}{ TN } & \multicolumn{2}{|c|}{ TC } & \multirow{2}{*}{ TC/TN } \\
\cline { 3 - 4 } & $(\%)$ & \multicolumn{2}{|c|}{$\left(\mathrm{g} \mathrm{kg}^{-1} \mathrm{DM}\right)$} & \\
\hline SMS-1 & 22.8 & 23.3 & 303 & 13.0 \\
SMS-2 & 41.6 & 25.9 & 312 & 12.0 \\
SMS-3 & 27.5 & 23.6 & 299 & 12.7 \\
SMS-4 & 42.8 & 23.7 & 301 & 12.7 \\
SMS-5 & 38.9 & 20.0 & 237 & 11.8 \\
SMS-6 & 37.0 & 19.6 & 233 & 11.9 \\
SMS-7 & 36.7 & 20.6 & 244 & 11.8 \\
SMS-8 & 28.0 & 23.8 & 304 & 12.8 \\
\hline Mean & & & & \\
Standard deviation & 34.4 & 22.6 & 279 & 12.4 \\
Relative standard & 7.35 & 2.23 & 34.4 & 0.47 \\
deviation (\%) & 21.4 & 9.88 & 12.3 & 3.93 \\
\hline
\end{tabular}

elements. According to MAZur and Mokra (2009), the content of nitrogen in fresh biomass of the spent mushroom substrate approximates the content of this element in natural fertilizers. The recorded TC/TN values suggest a high degree of organic matter transformation in the examined samples. The low value of coefficient of variation indicates that this quotient is a very stable characteristic. The TC/TN values are comparable with the levels in the humus horizons of arable mineral soil with good conditions for mineralization of organic matter (Kalembasa, Becher 2009b, Becher, Kalembasa 2011). It is supposed that the application of spent mushroom substrate will not significantly influence a change in the ratio between these compounds in soil and will probably prompt intensification of the mineralization of organic nitrogen compounds. The results reported by other authors (ZMORA-NAHUM et al. 2007, JoRDAN et al. 2008, Kalembasa, Majchrowska-Safaryan 2009, Rutkowska et al. 2009, KalemBASA, BECHER 2011) have indicated some differences in the content of $\mathrm{C}$ and $\mathrm{N}$ and $\mathrm{C} / \mathrm{N}$ ratio in spent mushroom substrates depending on the method of preparation, especially on the components and cultivation technology.

A characteristic feature of the tested spent mushroom substrates was considerable variation in the content and proportion of mineral nitrogen forms (Table 5) and a substantial advantage (app. 10-time) of reduced am-

Table 5

Content and proportion of mineral and organic nitrogen forms in the spent mushroom substrates

\begin{tabular}{|l|c|c|c|c|c|c|}
\hline \multirow{2}{*}{ Parameter } & \multicolumn{2}{|c|}{$\mathrm{N}_{\mathrm{MIN}}$} & \multicolumn{2}{c|}{$\mathrm{N}_{\mathrm{ORG}}$} & $\mathrm{N}-\mathrm{NH}_{4}$ & $\mathrm{~N} \mathrm{NO}_{\mathrm{x}}$ \\
\cline { 2 - 7 } & $\left(\mathrm{g} \mathrm{kg}^{-1} \mathrm{DM}\right)$ & $(\% \mathrm{TN})$ & $\left(\mathrm{g} \mathrm{kg}^{-1} \mathrm{DM}\right)$ & $(\% \mathrm{TN})$ & \multicolumn{2}{c|}{$\left(\mathrm{g} \mathrm{kg}^{-1} \mathrm{DM}\right)$} \\
\hline Mean & 1.02 & 4.65 & 21.5 & 95.3 & 0.94 & 0.09 \\
Range & $0.510-1.44$ & $2.19-7.04$ & $18.2-25.1$ & $93.0-97.8$ & $0.49-1.26$ & $0.02-0.18$ \\
SD & 0.323 & 1.73 & 2.42 & 1.73 & 0.28 & 0.05 \\
Relative SD (\%) & 31.5 & 37.3 & 11.2 & 1.82 & 29.7 & 60.0 \\
\hline
\end{tabular}


monia form (as an effect of ammonification) over oxidized nitrate forms. In other studies, it has been found that the proportion of mineral nitrogen forms was lower and amounted to, on average, 2.62\% TN (KALEMBASA, BECHER 2011).

The organic compounds constituted over $95 \%$ of the total nitrogen content. The sequential extraction allowed for recovery of organic nitrogen compounds in different forms (Table 6, Figure 1). The use of extraction reagents with incremental "extraction potency" $\left(0.25 \mathrm{M} \mathrm{KCl}<0.25 \mathrm{M} \mathrm{H}_{2} \mathrm{SO}_{4}<2.5 \mathrm{M}\right.$ $\mathrm{H}_{2} \mathrm{SO}_{4}<$ concentrated $\mathrm{H}_{2} \mathrm{SO}_{4}$ ) permitted the separation of nitrogen fractions which represented the organic compounds with varied susceptibility to microbiological degradation. The probable susceptibility of extracted organic nitrogen compounds to degradation in soil (following the application with fertilization) is arranged in the following order: $\mathrm{N}_{\mathrm{OR}}>\mathrm{N}_{\text {OєH }}>\mathrm{N}_{\text {Отн }}>\mathrm{N}_{\mathrm{ONH}}$.

Thanks to the applied extraction procedure, app. $2 / 3$ of the total nitrogen reserves in organic compounds was extracted. Assuming the proportion of nitrogen, the selected forms can be arranged in the following order of increasing quantitative importance: $\mathrm{N}_{\mathrm{OR}}<\mathrm{N}_{\mathrm{OTH}}<\mathrm{N}_{\mathrm{OEH}}<\mathrm{N}_{\mathrm{ONH}}$. In the case of carbon, the efficiency of extraction with the reagent was substantially lower as only 31.1 - 37.4\% of the total carbon pool was extracted (Table 7, Figure 2).

Nitrogen and carbon which can be extracted with a neutral reagent at a low concentration $(0.25 \mathrm{M} \mathrm{KCl})$ are the components of organic compounds

Table 6

Content of organic nitrogen forms $\left(\mathrm{g} \mathrm{kg}^{-1} \mathrm{DM}\right)$ in the spent mushroom substrates

\begin{tabular}{|l|c|c|c|c|c|}
\hline \multicolumn{1}{|c|}{ Parameter } & $\mathrm{N}_{\text {OR }}$ & $\mathrm{N}_{\text {Оєн }}$ & $\mathrm{N}_{\text {Оєн }}-\mathrm{NH}_{4}$ & $\mathrm{~N}_{\text {Отн }}$ & $\mathrm{N}_{\text {ОNн }}$ \\
\hline Mean & 3.12 & 5.49 & 1.27 & 4.77 & 6.93 \\
Range & $2.50-3.99$ & $4.59-6.18$ & $1.05-1.75$ & $3.86-5.69$ & $5.43-8.50$ \\
SD & 0.507 & 0.497 & 0.209 & 0.699 & 1.22 \\
Relative SD (\%) & 16.2 & 9.06 & 16.4 & 14.6 & 17.5 \\
\hline
\end{tabular}

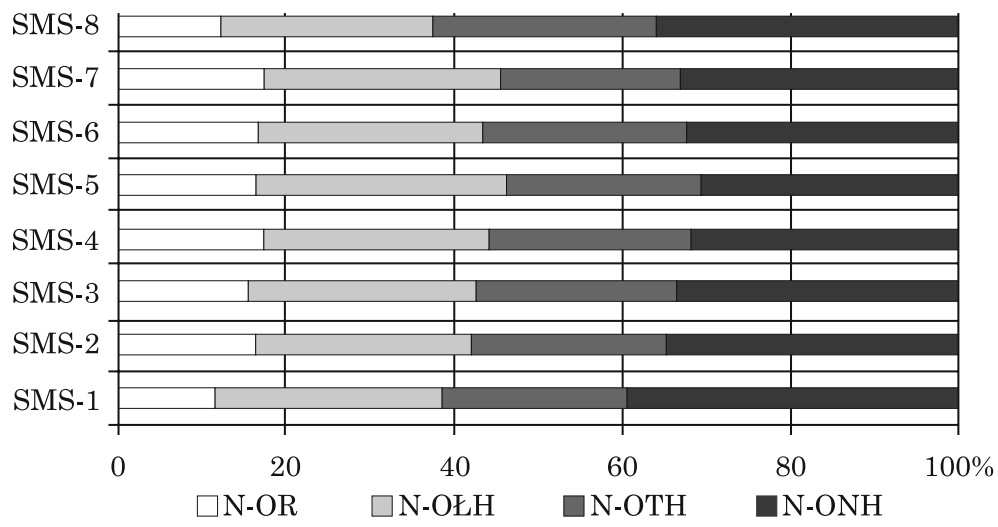

Fig. 1. Proportion of the selected nitrogen fractions in spent mushroom substrates $\left(\% \mathrm{~N}_{\mathrm{ORG}}\right)$ 
Content of organic carbon forms $\left(\mathrm{g} \mathrm{kg}^{-1} \mathrm{DM}\right)$ in the spent mushroom substrates

\begin{tabular}{|l|c|c|c|c|}
\hline \multicolumn{1}{|c|}{ Parameter } & $\mathrm{C}_{\mathrm{OR}}$ & $\mathrm{C}_{\text {Оєн }}$ & $\mathrm{C}_{\text {отн }}$ & $\mathrm{C}_{\text {ОNн }}$ \\
\hline Mean & 23.3 & 44.4 & 29.2 & 182 \\
Range & $19.2-28.8$ & $38.0-51.3$ & $24.0-35.5$ & $148-209$ \\
SD & 3.10 & 4.50 & 4.00 & 26.8 \\
Relative SD (\%) & 13.2 & 10.2 & 13.8 & 14.7 \\
\hline
\end{tabular}

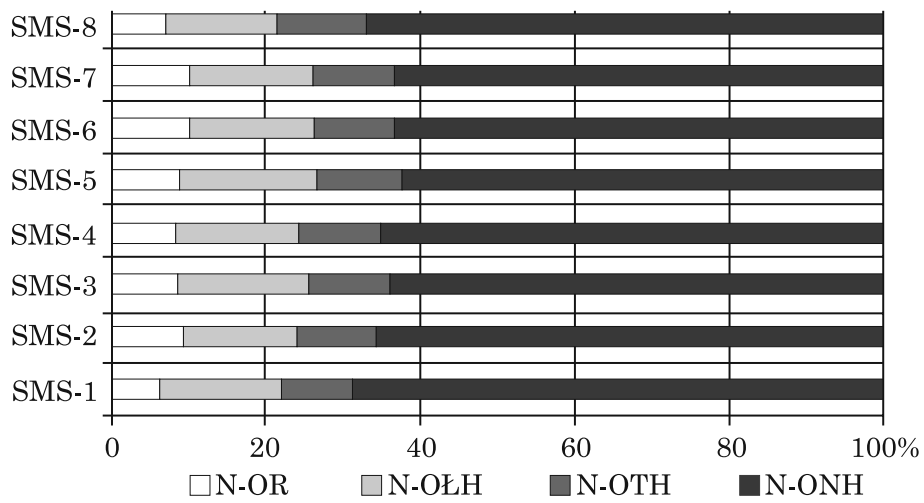

Fig. 2. Proportion of the selected carbon fractions in spent mushroom substrates (\%TC)

that probably represent the so-called dissolved organic matter (DON - dissolved organic nitrogen, DOC - dissolved organic carbon). This is the most mobile fraction and may comprise carbohydrates, amino acids, hydrocarbons and their derivatives, low-molecular humic acid fractions and other simple organic compounds (Mcdowell 2003, DębSka 2004, Paul, Williams 2005).

Of the form extracted with acid hydrolysis, on average $47.7 \%$ of the total organic nitrogen was separated with a minor advantage of readily hydrolysing form $\left(\mathrm{N}_{\mathrm{OЕH}}\right)$ - Figure 1. Moreover, on average, $1.27 \mathrm{~g} \mathrm{~kg}^{-1} \mathrm{~N}$ as ammonia form $\left(\mathrm{N}_{\mathrm{OŁH}}-\mathrm{NH}_{4}\right)$ was detected, which constituted on average $5.90 \%$ of organic nitrogen in the tested material (Table 6).

During acid hydrolysis, nitrogen bound to the humic matter and nitrogen incorporated in microbial proteins is released into a solution and is partially hydrolysed to ammonium, amino acids, amino sugars and other organic compounds (KaLEMBASA 1995).

While investigating different types of soil, Sowden et al. (1977) found that hydrolysing nitrogen constituted $84-89 \%$ of the total content of this element (following hydrolysis in $6 \mathrm{M} \mathrm{HCl}$ ) with nitrogen in amino acids amounting to $33-42 \%$, in amino sugars $-4.5-7.4 \%$, and in ammonia form $-18-32 \%$. The studies on organic soil (KALEMBASA, BECHER 2009a) have demonstrated (with the same method) that the proportion of hydrolysing nitrogen ranges from $43-64 \%$. 
Non-hydrolysing organic nitrogen constituted the largest pool (30.7$39.4 \%$ ) of organic nitrogen reserves in the examined spent mushroom substrates (Figure 1). Schulten and Schnitzer (1998) reported that within the fractions of non-hydrolysing nitrogen, derivatives of aromatic and heterocyclic compounds were predominant. KNICKER et al. (1995) suggested that the organic matter in soil contained peptide structures resistant to microbiological degradation.

The application of the tested substrate for fertilization at the dose permitted by the Nitrates Directive - $170 \mathrm{~kg} \mathrm{~N} \mathrm{ha}^{-1}$ (Code ... 2004), i.e. app. $7.5 \mathrm{t}$ DM ha-1, will enrich soil in app. $31 \mathrm{~kg} \mathrm{~N}^{-1}$ in mineral and soluble organic forms (that potentially mineralize very rapidly) and app. $77 \mathrm{~kg} \mathrm{~N}$ in hydrolysing forms, including $41 \mathrm{~kg}$ in easily hydrolysing form.

The determination of carbon content in the individual fractions allowed for calculation of carbon-to-nitrogen ratios which is the parameter commonly referred to in discussions on the vulnerability of organic compounds to mineralization. In general, the value of this quotient in the recovered fractions was characterized by minor variations in the recovered extracts (Table 8).

Table 8

Quotients of carbon and nitrogen contents in the selected fractions

\begin{tabular}{|l|c|c|c|c|}
\hline \multicolumn{1}{|c|}{ Parameter } & $\mathrm{C}_{\text {OR }} / \mathrm{N}_{\text {КСl }}$ & $\mathrm{C}_{\text {оєH }} / \mathrm{N}_{\text {Оєн }}$ & $\mathrm{C}_{\text {отн }} / \mathrm{N}_{\text {отн }}$ & $\mathrm{C}_{\text {ONH }} / \mathrm{N}_{\text {ONH }}$ \\
\hline Mean & 5.66 & 8.09 & 6.14 & 26.4 \\
Range & $5.06-6.38$ & $7.35-8.93$ & $5.75-6.52$ & $24.5-29.1$ \\
SD & 0.469 & 0.477 & 0.263 & 1.50 \\
Relative SD (\%) & 8.29 & 5.90 & 4.28 & 5.67 \\
\hline
\end{tabular}

These values also confirm the qualitative changes of organic compounds found in the recovered extracts. The narrowest $\mathrm{C} / \mathrm{N}$ ratios $(<10)$ were detected in the solution after extraction of the substrate with potassium chloride and in both hydrolysates ( 0.25 and $\left.2.5 \mathrm{M} \mathrm{H}_{2} \mathrm{SO}_{4}\right)$. The lowest value of this

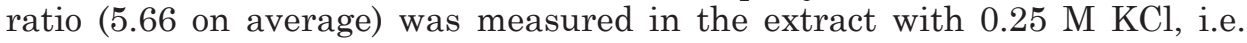
in the pool of soluble organic compounds $\left(\mathrm{C}_{\mathrm{OR}} / \mathrm{N}_{\mathrm{KCl}}\right)$. It confirms the highest potential susceptibility of organic compounds which represent this fraction to degradation in soil. The narrower ratio was detected in the fraction that was difficult to hydrolyse (6.14 on average) in comparison with the easily hydrolysing fraction (8.09 on average). The value of this ratio demonstrates that organic compounds extracted with acid hydrolysis are probably susceptible to mineralization. The widest $\mathrm{C} / \mathrm{N}$ value was determined in the non-hydrolysing fraction, which probably confirms the highest resistance of organic compounds that are left in the examined material after extraction procedures (residuum) to microbiological degradation. Following the application of substrate as a fertilizer, the group of these organic compounds will show the longest life in soil.

The content and proportion of nitrogen in the fraction generated with 
the procedure of extraction of organic matter are presented in Table 9. A relatively large amount of nitrogen extracted at the stage of decalcification of the samples $\left(\mathrm{N}_{\mathrm{DEKA}}\right)$ was detected. This fraction is probably represented mainly by simple organic compounds which are relatively low-molecular, loose and poorly bound to mineral components of the examined material and potentially most labile in soil after the application with fertilization (STEVENSON 1985). A minor fraction of nitrogen that passes into $0.05 \mathrm{M} \mathrm{H}_{2} \mathrm{SO}_{4}$ extract also represents the mineral forms of this element.

Table 9

Content $\left(\mathrm{g} \mathrm{kg}^{-1} \mathrm{DM}\right)$ and proportion of nitrogen in the fractions of organic matter in the spent mushroom substrates

\begin{tabular}{|l|c|c|c|c|c|c|}
\hline \multicolumn{1}{|c|}{ Parameter } & $\mathrm{N}_{\mathrm{DEKA}}$ & $\mathrm{N}_{\mathrm{SH}}$ & $\mathrm{N}_{\mathrm{KH}}$ & $\mathrm{N}_{\mathrm{KF}}$ & $\mathrm{N}_{\mathrm{SNH}}$ & $\mathrm{N}_{\mathrm{KH}} / \mathrm{N}_{\mathrm{KF}}$ \\
\hline Mean & 3.52 & 4.96 & 2.53 & 2.43 & 14.1 & 1.11 \\
Range & $2.12-4.32$ & $3.36-7.59$ & $1.68-3.44$ & $1.50-4.15$ & $11.9-16.5$ & $0.83-1.59$ \\
SD & 0.782 & 1.33 & 0.488 & 0.901 & 1.55 & 0.29 \\
Relative SD (\%) & 22.2 & 26.8 & 19.3 & 37.1 & 11.0 & 26.0 \\
\hline \% TN & & & & & & \\
Mean & 15.8 & 21.7 & 11.1 & 10.6 & 62.5 & - \\
Range & $9.10-20.0$ & $16.8-29.3$ & $8.40-13.3$ & $7.65-16.0$ & $57.5-70.6$ & \\
\hline
\end{tabular}

During alkaline extraction (with $0.1 \mathrm{M} \mathrm{NaOH}$ ), slightly over $1 / 5$ of the nitrogen pool was extracted (Table 9). The organic compounds in this fraction probably represent the part which is transformed as a result of humification. In the examined material, the proportion of fulvic acids was more variable. A minor advantage of nitrogen in the more stable fraction of humic acids was detected. Fulvic acids, as a fraction of the humus which is soluble in a wider array of reagents (e.g. in acidic solutions), were partially extracted in the first phase of the procedure, i.e. with $0.05 \mathrm{M} \mathrm{H}_{2} \mathrm{SO}_{4}$. In the examined material, the residual fraction $\left(\mathrm{N}_{\mathrm{SNH}}\right)$ which constituted the largest proportion should be largely categorized as non-humified organic matter and, to a minor extent, as humins. It probably contains difficult to degrade organic residues (lignin and cellulose) which are genetically associated with straw and peat (used in the production of mushroom substrate).

\section{CONCLUSIONS}

1. The mushroom substrates used to cultivate common mushroom, Agaricus bisporus, had considerable potential for enriching fertilized soil in mineral and organic nitrogen compounds which were substantially susceptible to degradation in soil. 
2. With the sequential extraction, app. 2/3 of the total organic nitrogen pool and app. 1/3 of the carbon pool were extracted.

3. The proportion of nitrogen in humic substances constituted app. 1/5 of the total pool of this element.

4. The presented procedure of extraction may serve as a potential method of qualitative evaluation of organic nitrogen with a perspective for judicious use of waste organic materials in soil fertilization.

5. Further research is warranted in order to investigate the relations between the proportions of individual fractions and the release of nitrogen during mineralization and the possibility for its absorption by plants (in conjunction with time and soil conditions). Furthermore, it is recommended to conduct a qualitative analysis of organic nitrogen compounds which represent the individual fractions.

\section{REFERENCES}

Becher M. 2013. Properties of organic matter of soil fertilised with spent mushroom (Agaricus L.) substrate. Acta Agroph., 20(2): 241-252.

Becher M., Kalembasa D. 2011. Fractions of nitrogen and carbon in humic layers of brown earth arable fields in Siedlecka Upland. Acta Agroph., 18(1): 7-16. (in Polish)

Code of Good Agricultural Practice. 2004. MRiRW i MŚ, Warszawa.

DęBska B. Properties of humic substances in soil fertilized with slurry. 2004. Rozprawy ATR Bydgoszcz, 110: $112 \mathrm{pp}$.

Dziadowiec H., Guidebook on the methodology on soil organic matter research. Gonet S.S. 1999. Wyd. Pr. Kom. Nauk., PTG, 120, Warszawa.

Jordan S. N., Mullen G. J., Murphy M.C. 2008. Composition variability of spent mushroom compost In Ireland. Biores. Technol., 99: 411-418.

Kalembasa D., Becher M. 2009a. Fractions of nitrogen in peat muck soils in the upper Liwiec River valley. Woda-Środowisko-Obszary Wiejskie 9, 2 (26): 73-82.

Kalembasa D., Becher M. 2009b. Properties of organic matter in chosen soils fertilized with sewage sludge. Environ. Protect. Engine., 35(2): 165-171.

Kalembasa D., Becher M. 2011. Nitrogen and carbon extracted by acid hydrolysis from spent mushroom substrate. Inż. Ekol., 27: 26-32. (in Polish)

Kalembasa D., Becher M. 2012. Speciation of carbon and selected metals in spent mushroom substrates. J. Elem., 17, 3: 409-419.

Kalembasa D., Majchrowska-Safaryan A. 2009. Nutrient abundance of spent mushroom substrate. Zesz. Probl. Post. Nauk Rol., 535: 195-200.

KaLEMbasa S. 1991. Quick method of determination of organic carbon in soil. Pol. J. Soil Sci., 24(1), 17-22.

Kalembasa S. 1995. Use of ${ }^{15} \mathrm{~N}$ and ${ }^{13} \mathrm{~N}$ isotopes in soil research and chemical and agricultural studies. WNT, Warszawa, $251 \mathrm{ss.}$

Knicker H., Almendros G., Gonzales-Vila F. J., Luedemann H. D., Martin F. 1995. 13-C and 15-N NMR analysis of some fungal melanins in comparison to soil organic matter. Org. Geochem., 23: 1023-1028.

Mazur Z., Mokra O. 2009. Content of macronutrients in natural fertilizers in Poland, in 2003-2005. Zesz. Probl. Post. Nauk Rol., 537: 243-248. 
McDowell W. H. 2003. Dissolved organic matter in soils - future directions and unanswered questions. Geoderma, 113: 179-186.

Medina E., Paredes C., Perez-Muria M.D., Bustamante M.A., Moral R. 2009. Spent mushrum substrates as component of growing media for germination and growth of horticultural plants. Biores. Technol., 100: 4227-4232.

PakuŁa K., Kalembasa D. 2012. Macronutrients in arable lands in Siedlecka Upland. Acta Agroph., 19(4): 803-814. (in Polish)

Paul J. P., Williams B. L. 2005. Contribution of $\alpha$-amin $N$ to extractable organic nitrogen (DON) in three soil types the Scottish uplands. Soil Biol. Biochem., 37: 801-803.

Regulation of the Minister for the Envrionment of 27 September 2001, on the catalogue of waste. Dz. U. Nr 112, poz. 1206.

Rutkowska B., Szulc W., StęPień W., Jobda J. 2009. Possibilities of agricultural utilization of spent mushroom substrate. Zesz. Probl. Post. Nauk Rol., 535: 349-356. (in Polish)

Schulten H.R., Schnitzer M. 1998. The chemistry of soil organic nitrogen: a review. Biology and Fertility of Soils, 26: 1-15.

Sowden F.J., Chen Y., Schnitzer M. 1977. The nitrogen distribution in soils formed under widely differing climatic conditions. Geochim. Cosmochim. Acta, 41: 1524-1526.

Stevenson F.J. 1985. Geochemistry of soil humic substances. In: Humic substances in soil, sediment and waste. John Wiley and Sons, New York, 13-53.

Stewart D.P.C., Cameron K.C., Confort I.S. 1998. Effect of spent mushroom substrate on soil chemical conditions and plant growth in an intensive horticultural system: a comparison with inorganic fertiliser. Austral., J. Soil Res., 36, 2: 75-83.

Zmora-Nahum S., Hadar Y., Chen Y. 2007. Physico-chemical properties of commercial composts varying in their source materials and country of origin. Soil Biol. Biochem., 39: 1263-1276. 